\title{
Vertical Distribution Characteristics of the Phenotypic Traits of High- Yielding Wheat Varieties Under Limited Irrigation and Nitrogen Supply
}

\author{
He-Cang Zang ( $\nabla$ zanghecang@163.com ) \\ Henan Academy of Agricultural Sciences \\ Yan-Jing Wang \\ Zhengzhou Normal University \\ Yun-Peng Liu \\ China Agricultural University \\ Ying-Hua Zhang \\ China Agricultural University \\ Guo-Qing Zheng \\ Henan Academy of Agricultural Sciences \\ Guo-Qiang Li \\ Henan Academy of Agricultural Sciences \\ Zhi-Min Wang \\ China Agricultural University
}

\section{Research Article}

Keywords: Limited irrigation and nitrogen, wheat, leaf characteristics, stem characteristics, phenotypic traits, vertical distribution

Posted Date: January 25th, 2022

DOI: https://doi.org/10.21203/rs.3.rs-1255661/v1

License: (c) (i) This work is licensed under a Creative Commons Attribution 4.0 International License. Read Full License 


\section{Abstract}

To clarify the vertical distribution characteristics of the phenotypic traits of high-yielding wheat varieties, the canopy was used as the system, with the leaf position and node position as the level, stratified from top to bottom. The morphological structure characteristics of the leaf layer, node layer and light transmittance of the high-yielding wheat varieties under limited irrigation and nitrogen supply were studied and discussed. The results showed that two-year test yield and nitrogen fertilizer production efficiency (NPF) were the highest in the spring irrigation at jointing and anthesis stages (W2) and $192 \mathrm{~kg} / \mathrm{hm} 2$ (N1), which achieved high yield and efficient nitrogen utilization. With the decrease of the leaf layer from top to bottom, the leaf area of the two wheat varieties displayed a trend of being higher in the upper layer and lower in the lower layer, while the light transmittance showed a decreasing trend. As the node layer decreased from top to bottom, the node length of the two wheat varieties decreased sequentially. Comprehensive research suggested that appropriate irrigation and nitrogen input improved the vertical distribution characteristics of wheat phenotypic traits, and can obtain higher grain yield and nitrogen fertilizer production efficiency.

\section{Introduction}

Wheat is an important food crop in North China, and an increase in its output is important for the country's food security (Yang et al. 2021; Zhao et al. 2017; Zang et al. 2012). However, in actual production, farmers commonly apply excessive amounts of irrigation and nitrogen, leading to environmental pollution and reduced irrigation and nitrogen use efficiencies as well as product quality (Jing et al. 2007; Drinkwater et al. 2007; Wang et al. 2006; Zhang et al. 2007). Therefore, appropriate irrigation and nitrogen supply promote the effective distribution of plant components substances, and ensured production is an important way to achieve high yields and efficient utilization of irrigation and nitrogen by wheat.

Phenotypic traits are the combination form and overall expression of comprehensive biological traits formed by crop yield. Clarification of the phenotypic trait distribution characteristics of high-yielding wheat varieties can provide references for breeding water-saving and high-yield wheat. The ideal plant type selection was the basis for water-saving cultivation and high-yield breeding of dryland wheat, leaf type was mainly featured by erect leaf, the flag leaf length and width ratio was moderate, and the length of the first two leaves was approximately $20 \mathrm{~cm}$ (Li et al. 2011). Studies have shown that nitrogen application significantly increases the leaf length, single leaf area and SPAD value of different wheat varieties (Li et al. 2011; Vos et al. 2005), and excessive nitrogen application leads to higher plant growth and longer internodes (Laghari et al. 2010).

Nitrogen reduction can increase the light transmittance ratio of the lower canopy after anthesis and can improve the light transmittance through of the lower canopy (Ma et al. 2019). As the amount of nitrogen increased, the plant height, leaf area index and photosynthetically active radiation intercepted by the canopy increased (Zhang et al. 2018). Lower nitrogen supply promotes the transfer of dry matter from the third leaves, the fourth leaves, the third nodes, the fourth nodes and remaining nodes of wheat plants to the grain, which was beneficial to increase the grain yield (Jiang et al. 2019). Through hydroponic experiments to study the effects of low nitrogen supply on the photosynthesis and nitrogen status of different wheat leaves, which indicated that the area of the first leaf of two wheat varieties was significantly reduced, but that of the second and third leaves did not vary significantly (Li et al. 2013). At a nitrogen application rate of $225 \mathrm{~kg} / \mathrm{hm}^{2}$, the thicknesses of the second and third internodes at the base of two wheat cultivars were greater than those of other nitrogen treatments (Zhou et al. 2019). Previous studies mainly focused on the leaf shape, and there are few studies on the combination of the leaf position and node position. The vertical distributions of the leaf position and the node position of different wheat varieties are less reported under water-limited irrigation, and knowledge of these topics is unclear, especially under the limited irrigation resources in North China. Therefore, this study selected two main wheat varieties (high-yield, waterefficient and drought-resistant varieties) in the experimental area to systematically examine the vertical distribution changes of canopy morphology and physiological characteristics and to explore the individual plant types of wheat under different irrigation and nitrogen regimes. This study is expected to provide a scientific basis and technical guidance for the shaping of a highly efficient canopy structure for water-efficient wheat cultivation.

\section{Materials And Methods}

\section{Test site and meteorological conditions}

Field trials were carried out at the Wuqiao experimental station of China Agricultural University in Wuqiao County, Hebei Province, from 2009 to 2011. Wuqiao is located in the middle of the Heilonggang Basin of the Haihe Plain, which has a warm temperate monsoon climate. The test site was located at $116^{\circ} 37^{\prime} 23^{\prime \prime}$ east longitude and $37^{\circ} 41^{\prime} 02^{\prime \prime}$ north latitude, with an average annual sunshine duration of 2767.1 hours and an average annual temperature of $12.5^{\circ} \mathrm{C}$. The average annual rainfall is $676.9 \mathrm{~mm}$, and the rainfall in the wheat season from 2009 to 2010 was $116.3 \mathrm{~mm}$, which was a normal year. The rainfall in the wheat season from 2010 to 2011 was $62.4 \mathrm{~mm}$ (Table 1). 
Table 1

Meteorological conditions during the winter wheat growing period from 2009 2011

\begin{tabular}{|c|c|c|c|c|c|c|c|c|c|c|c|}
\hline \multirow[t]{2}{*}{ Year } & \multirow[t]{2}{*}{ Weather index } & \multicolumn{9}{|l|}{ Month } & \multirow[t]{2}{*}{ Total } \\
\hline & & 10 & 11 & 12 & 1 & 2 & 3 & 4 & 5 & 6 & \\
\hline 2009 & Amount of precipitation (mm) & 26.0 & 19.0 & 9.1 & 5.0 & 7.8 & 10.9 & 8.8 & 24.6 & 5.4 & 116.6 \\
\hline$\sim$ & Average temperature $\left({ }^{\circ} \mathrm{C}\right)$ & 15.6 & 2.4 & -1.6 & -3.7 & 0.0 & 5.0 & 11.4 & 21.0 & 24.4 & 74.5 \\
\hline 2010 & Sunshine duration (h) & 269.9 & 163.4 & 177.6 & 214.0 & 148.3 & 208.8 & 261.3 & 303.7 & 186.6 & 1933.6 \\
\hline 2010 & Amount of precipitation (mm) & 4.1 & 0.0 & 0.0 & 0.1 & 7.2 & 0.0 & 14.9 & 36.2 & 0.0 & 62.4 \\
\hline$\sim$ & Average temperature $\left({ }^{\circ} \mathrm{C}\right)$ & 12.9 & 5.9 & -0.5 & -6.4 & -1.1 & 7 & 13.8 & 19.6 & 26.1 & 77.7 \\
\hline 2011 & Sunshine duration (h) & 230.5 & 244.8 & 229.4 & 233.4 & 150.8 & 283.7 & 279.2 & 281.1 & 263.2 & 2196.1 \\
\hline
\end{tabular}

The first crop of the test field was silage summer maize, and the soil was loamy bottom clay aquic soil. See Table 2 for the basic soil fertility of the $0-20 \mathrm{~cm}$ soil layer before planting.

Table 2

Agro-chemical characteristics of the tested soil

\begin{tabular}{|llllll|}
\hline Year & $\begin{array}{l}\text { O.M. } \\
(\mathbf{g} / \mathbf{k g})\end{array}$ & $\begin{array}{l}\text { Total N } \\
(\mathbf{g} / \mathbf{k g})\end{array}$ & $\begin{array}{l}\text { Available N } \\
(\mathbf{m g} / \mathbf{k g})\end{array}$ & $\begin{array}{l}\text { Available P } \\
(\mathbf{m g} / \mathbf{k g})\end{array}$ & $\begin{array}{l}\text { Available K } \\
(\mathbf{m g} / \mathbf{k g})\end{array}$ \\
\hline 2009 2010 & 11.0 & 1.1 & 68.6 & 49.1 & 123.7 \\
\hline $2010 \sim 2011$ & 12.0 & 1.1 & 72.6 & 44.2 & 132.3 \\
\hline
\end{tabular}

\section{Experimental design}

Test one (2009 2010)

The tested wheat varieties were Jimai 22 and Shimai 15. Each variety had two water-efficient irrigation modes (W1, W2) and two nitrogen levels $(\mathrm{N} 1, \mathrm{~N} 2)$. On the basis of suitable moisture during sowing, two water-efficient irrigation modes were established: W1 (spring irrigation at jointing stage) and W2 (spring irrigation at jointing and anthesis stages); and two nitrogen fertilizer treatments: N1 (base fertilizer: 123 kg/hm² + topdressing $69 \mathrm{~kg} / \mathrm{hm}^{2}$ at the jointing stage) and N2 (base fertilizer: $123 \mathrm{~kg} / \mathrm{hm}^{2}+$ topdressing $147 \mathrm{~kg} / \mathrm{hm}^{2}$ at the jointing stage). The combinations were W1N1, W1N2, W2N1 and W2N2. The area of each plot was $54 \mathrm{~m}^{2}$, with three replicates, and the distance between plots was $0.6 \mathrm{~m}$. The seedlings were sown on October 16,2009 , with a basic seedling density of $510 \times 10^{4}$ plants $/ \mathrm{hm}^{2}$ and a row spacing of $16 \mathrm{~cm}$.

Before the wheat was sown, the corn stalks were crushed and returned to the field, after which organic fertilizer ( $50 \%$ chicken manure $+50 \%$ soil manure), $15 \mathrm{~m}^{3} / \mathrm{hm}^{2}$; urea, $150 \mathrm{~kg} / \mathrm{hm}^{2}$; diammonium phosphate, $300 \mathrm{~kg} / \mathrm{hm}^{2}$; and potassium sulfate, $225 \mathrm{~kg} / \mathrm{hm}^{2}$ were applied. A random block arrangement was adopted and repeated three times. In the jointing period, the abovementioned treatments were combined with irrigation and nitrogen fertilizer topdressing. The irrigation water measurements and other field management measures refer to water-efficient and high-yield cultivation techniques for wheat. The wheat was harvested on June 15, 2010. See Table 3 for the specific treatments.

Table 3

Different irrigation and nitrogen regimes

\begin{tabular}{|c|c|c|c|c|}
\hline Regime & $\begin{array}{l}\text { Sowing } \\
\text { date }\end{array}$ & Density & Nitrogen & Irrigation \\
\hline W1N1 & \multirow[t]{4}{*}{2009.10 .16} & \multirow{4}{*}{$\begin{array}{l}510 \times 10^{4} \\
\text { plants } / \mathrm{hm}^{2}\end{array}$} & Base fertilizer $123 \mathrm{~kg} / \mathrm{hm}^{2}+$ topdressing $69 \mathrm{~kg} / \mathrm{hm}^{2}$ & Jointing water \\
\hline W1N2 & & & $\begin{array}{l}\text { Base fertilizer } 123 \mathrm{~kg} / \mathrm{hm}^{2}+\text { topdressing } 147 \\
\mathrm{~kg} / \mathrm{hm}^{2}\end{array}$ & Jointing water \\
\hline W2N1 & & & Base fertilizer $123 \mathrm{~kg} / \mathrm{hm}^{2}+$ topdressing $69 \mathrm{~kg} / \mathrm{hm}^{2}$ & $\begin{array}{l}\text { Jointing water + flowering } \\
\text { water }\end{array}$ \\
\hline W2N2 & & & $\begin{array}{l}\text { Base fertilizer } 123 \mathrm{~kg} / \mathrm{hm}^{2}+\text { topdressing } 147 \\
\mathrm{~kg} / \mathrm{hm}^{2}\end{array}$ & $\begin{array}{l}\text { Jointing water + flowering } \\
\text { water }\end{array}$ \\
\hline
\end{tabular}

Test 2 (2010 2011) 
The tested wheat variety was Shimai 15. A water-nitrogen model test was established, and the specific codes for each regime are shown in Table 4. The plot area was $54 \mathrm{~m}^{2}$, the plots were arranged in random blocks, repeated 3 times, and the plots were separated by $0.6 \mathrm{~m}$. The seedlings were sown on October 17,2010 , with a basic seedling density of $530 \times 10^{4}$ plants $/ \mathrm{hm}^{2}$ and a row spacing of $15 \mathrm{~cm}$. Water plantar moisture before sowing wheat, and top dressing was carried out in conjunction with irrigation during the jointing stage. In each treatment, the corn stalks were crushed and returned to the field before sowing, and organic fertilizer (50\% chicken manure $+50 \%$ soil manure), $15 \mathrm{~m}^{3} / \mathrm{hm}^{2} ; \mathrm{urea}, 150 \mathrm{~kg} / \mathrm{hm}^{2}$; diammonium phosphate, $300 \mathrm{~kg} / \mathrm{hm}^{2}$; potassium sulfate, $225 \mathrm{~kg} / \mathrm{hm}^{2}$; and zinc sulfate, $15 \mathrm{~kg} / \mathrm{hm}^{2}$ were applied. A random block arrangement was adopted and repeated three times. In the jointing period, the abovementioned treatments were combined with irrigation and nitrogen fertilizer topdressing. Irrigation water measurements and other field management measures refer to water-efficient and high-yield cultivation techniques for wheat. The wheat was harvested on June 20, 2011. See Table 4 for the specific treatments.

Table 4

Different irrigation and nitrogen treatments

\begin{tabular}{|c|c|c|c|c|}
\hline Regime & Sowing date & Density & Nitrogen & Irrigation \\
\hline W1 Nb & 2010.10 .17 & $530 \times 10^{4}$ plants $/ \mathrm{hm}^{2}$ & Base fertilizer $123 \mathrm{~kg} / \mathrm{hm}^{2}$ & Jointing water \\
\hline W1N1 & & & Base fertilizer $123 \mathrm{~kg} / \mathrm{hm}^{2}+$ topdressing $69 \mathrm{~kg} / \mathrm{hm}^{2}$ & Jointing water \\
\hline W1N2 & & & Base fertilizer $123 \mathrm{~kg} / \mathrm{hm}^{2}+$ topdressing $155 \mathrm{~kg} / \mathrm{hm}^{2}$ & Jointing water \\
\hline W2Nb & & & Base fertilizer $123 \mathrm{~kg} / \mathrm{hm}^{2}$ & Jointing water + flowering water \\
\hline W2N1 & & & Base fertilizer $123 \mathrm{~kg} / \mathrm{hm}^{2}+$ topdressing $69 \mathrm{~kg} / \mathrm{hm}^{2}$ & Jointing water + flowering water \\
\hline W2N2 & & & Base fertilizer $123 \mathrm{~kg} / \mathrm{hm}^{2}+$ topdressing $155 \mathrm{~kg} / \mathrm{hm}^{2}$ & Jointing water + flowering water \\
\hline
\end{tabular}

\section{Test items and methods}

\section{Leaf shape determination}

Sampling was conducted during wheat anthesis, and representative samples of $2 \times 50 \mathrm{~cm}$ were collected from each test plot and transferred indoors. Twenty plants with uniform growth were selected, and the length and width of the flag leaf, the top two leaves, the top three leaves and the top four leaves were measured with a ruler. The leaf length was measured as the distance from the base of the leaf to the tip (cm), the leaf width was measured as the width from the base of the leaf to the widest point $(\mathrm{cm})$, and the green leaf area of the population was measured at the same time. From 2009 to 2010, the length and width coefficient method was used to determine the leaf area at different leaf positions. From 2010 to 2011, the single leaf area $\left(\mathrm{cm}^{2}\right)$ was measured using an LI-3000 leaf area meter produced by the American LI-COR company.

\section{Stem node morphology determination}

To determine the leaf morphology, the plant height, ear length and the length of each node were measured with a ruler. The stem thickness was measured with a Vernier caliper. Both tested varieties had five internodes, with the inferior internode as the first internode, followed by the second internode, the third internode, the fourth internode, and the belowground internode as the inverted fifth internode. The wheat plant height composition index was calculated as follows: $I_{L}=\left(L_{1}+L_{2}\right) / L$, and the index between two adjacent nodes was calculated as follows: $I_{n}=$ $L_{n} /\left(L_{n}+L_{n+1}\right)$, where $L$ is the plant height, $n$ is the node position from top to bottom, $L_{1}$ is the internode length beneath the panicle, and $L_{5}$ is the basal internode length.

\section{Determination of canopy transmittance}

At the booting stage, flowering stage, and 10 days and 20 days after flowering, the photosynthetically active radiation was measured by an LI191SA linear light quantum sensor produced in the United States on a sunny and windless day from 11:00 to 13:00. The wheat canopy was divided into the upper layer, middle layer and lower layer. The natural light intensity above the wheat corresponded to the upper layer, the middle layer was $2 / 3$ of the plant height based on the distance from the ground, and the lower layer was $1 / 3$ of the plant height from the ground. The formula for calculating the light transmittance of each layer was as follows: $T=I_{r} / I_{0} \times 100 \%, I_{r}$ is the light intensity of a specific leaf layer, and $I_{0}$ is the natural light intensity at the top of the wheat canopy.

\section{Grain yield}

At maturity, $4 \mathrm{~m}^{2}$ sample point were selected from each plot, and were harvested separately by hand. After threshing, they were air-dried to calculate yield. The moisture content of the grain was $13 \%$.

\section{Nitrogen production efficiency}

NPE was calculated according to the methods of Dordas and Sioulas (2009): 
NPE $(\mathrm{kg} / \mathrm{kg})=$ grain yield / $\mathrm{N}$ fertilizer rate

\section{Data analyses}

One-way analysis of variance (ANOVA) was performed in SPSS 19.0 (IBM Corp., Armonk, NY, USA). GraphPad Prism 5.0 (GraphPad Software, Inc., California, USA) was used to draw the figures. Regime means were compared using the least significant difference test considering $\mathrm{P}<0.05$ as significant.

\section{Results And Analysis}

\section{Wheat grain yield and nitrogen fertilizer production efficiency}

Table 5 shows that under the W1 level, the grain yield and nitrogen fertilizer production efficiency of Jimai 22 were not significantly different between the N1 and N2 treatments, while the grain yield and nitrogen production efficiency of Shimai 15 in the N1 regime were significantly higher than those in the N2 treatment. Under the W2 level, the grain yield and nitrogen production efficiency of the two wheat varieties in the N1 regime were significantly higher than those in the N2 treatment. Under the same level of nitrogen application, the grain yield and nitrogen production efficiency of the two wheat varieties in the W2 regime were higher than those in the W1 regime from 2009 to 2010, while in 2010 2011, the grain yield and nitrogen production efficiency of the W2 regime were higher than those in the W1 treatment. This showed that under the two waterlimited irrigation regimes in this experiment, the W2 regime was more conducive to improving the grain yield and nitrogen fertilizer production efficiency than the W1 regime. Under the W2 level, the N1 regime resulted in high wheat grain yield and nitrogen production efficiency.

Table 5

Grain yield and nitrogen fertilizer production efficiency of winter wheat under limited irrigation and nitrogen supply

\begin{tabular}{|c|c|c|c|c|}
\hline Year & Variety & Regime & $\begin{array}{l}\text { Grain yield } \\
\left(\mathrm{kg} / \mathrm{hm}^{2}\right)\end{array}$ & $\begin{array}{l}\text { NPE } \\
(\mathrm{kg} / \mathrm{kg})\end{array}$ \\
\hline \multirow[t]{10}{*}{ 2009 2010 } & \multirow[t]{5}{*}{ Jimai 22} & W1N1 & $8459.31 b$ & $22.01 \mathrm{a}$ \\
\hline & & W1N2 & $8762.20 \mathrm{~b}$ & $22.72 a$ \\
\hline & & W2N1 & $9557.48 a$ & $22.74 a$ \\
\hline & & W2N2 & $9152.84 a b$ & $21.70 \mathrm{a}$ \\
\hline & & Average & 8982.96 & 22.29 \\
\hline & \multirow[t]{5}{*}{ Shimai 15} & W1N1 & $8367.59 b$ & $23.07 a$ \\
\hline & & W1N2 & 7943.74c & $20.92 b$ \\
\hline & & W2N1 & $9349.04 a$ & $23.44 a$ \\
\hline & & W2N2 & $8596.77 b$ & $21.28 \mathrm{~b}$ \\
\hline & & Average & 8564.29 & 22.18 \\
\hline \multirow[t]{7}{*}{ 2010 2011 } & \multirow[t]{7}{*}{ Shimai 15} & W1Nb & $7174.23 c$ & $17.62 c$ \\
\hline & & W1N1 & $7441.94 c$ & $18.12 \mathrm{c}$ \\
\hline & & W1N2 & $7572.97 c$ & $17.65 c$ \\
\hline & & $\mathrm{W} 2 \mathrm{Nb}$ & $9353.31 b$ & $21.97 b$ \\
\hline & & W2N1 & $9954.61 a$ & $23.49 a$ \\
\hline & & W2N2 & $9613.52 a$ & $22.82 \mathrm{ab}$ \\
\hline & & Average & 8518.43 & 20.28 \\
\hline
\end{tabular}

From 2009 to 2010, the grain yields of the Jimai 22 and Shimai 15 in the W2N1 regime were $9349.04 \mathrm{~kg} / \mathrm{hm}^{2}$ and $9557.48 \mathrm{~kg} / \mathrm{hm}{ }^{2}$, and the nitrogen fertilizer production efficiencies of the Jimai 22 and Shimai 15 were $23.44 \mathrm{~kg} / \mathrm{kg}$ and $22.74 \mathrm{~kg} / \mathrm{kg}$. There was a large difference between the varieties: under different water and nitrogen regimes, the grain yield and nitrogen fertilizer production efficiency of Jimai 22 were higher than those of Shimai 15. The W2N1 regime resulted in the highest yield and nitrogen fertilizer production efficiency of both wheat varieties. Similarly, from 2010 to 2011, the two wheat varieties had the highest grain yield and nitrogen fertilizer production efficiency in the W2N1 treatment. 


\section{Leaf layer morphological characteristics}

Leaves are the most important photosynthetic organs of crops, and the size and spatial distribution of leaves are determined by the genetic characteristics of the variety and are also affected by the cultivation measures. Leaf characteristics are usually based on measurements of the leaf length, width and area. Table 6 and Table 7 show that with the decrease of the leaf layer from top to bottom, the leaf area of the two wheat varieties displayed a trend of being higher in the upper layer and lower in the lower layer. Under the same limited irrigation conditions, the area of each leaf layer in the N2 regime was higher than that in the N1 regime for both varieties. Table 6 shows that compared with the N1 treatment, the leaf area of a single stem of Jimai 22 in the N2 regime increased by 5.7\%, and the leaf area of a single stem of Shimai 15 in the N2 regime increased by $11.1 \%$. The comparison between varieties showed that the leaf area of Jimai 22 in each layer was significantly higher than that of Shimai 15 , which indicated that Jimai 22 had a relatively strong stabilization ability of the leaf area.

Table 6

Leaf configuration of individual plants at anthesis under limited irrigation and nitrogen supply (2009 2010)

\begin{tabular}{|c|c|c|c|c|c|c|c|c|c|c|c|c|c|c|}
\hline \multirow[t]{3}{*}{ Variety } & \multirow[t]{3}{*}{ Regime } & \multicolumn{3}{|c|}{ Flag leaf } & \multicolumn{3}{|c|}{ The second leaf } & \multicolumn{3}{|c|}{ The third leaf } & \multicolumn{4}{|c|}{ The fourth leaf } \\
\hline & & $\begin{array}{l}\text { Length } \\
(\mathrm{cm})\end{array}$ & $\begin{array}{l}\text { Width } \\
(\mathrm{cm})\end{array}$ & $\begin{array}{l}\text { Area } \\
\left(\mathrm{cm}^{2}\right)\end{array}$ & $\begin{array}{l}\text { Length } \\
(\mathrm{cm})\end{array}$ & $\begin{array}{l}\text { Width } \\
(\mathrm{cm})\end{array}$ & $\begin{array}{l}\text { Area } \\
\left(\mathrm{cm}^{2}\right)\end{array}$ & $\begin{array}{l}\text { Length } \\
(\mathrm{cm})\end{array}$ & $\begin{array}{l}\text { Width } \\
(\mathrm{cm})\end{array}$ & $\begin{array}{l}\text { Area } \\
\left(\mathrm{cm}^{2}\right)\end{array}$ & $\begin{array}{l}\text { Length } \\
(\mathrm{cm})\end{array}$ & $\begin{array}{l}\text { Width } \\
(\mathrm{cm})\end{array}$ & $\begin{array}{l}\text { Area } \\
\left(\mathrm{cm}^{2}\right)\end{array}$ & $\begin{array}{l}\text { Total } \\
\text { leaf } \\
\text { area }\end{array}$ \\
\hline & & & & & & & & & & & & & & $\left(\mathrm{cm}^{2}\right)$ \\
\hline \multirow{3}{*}{$\begin{array}{l}\text { Jimai } \\
22\end{array}$} & W1N1 & 15.0 & 1.7 & 20.7 & 19.8 & 1.5 & 24.1 & 19.7 & 1.3 & 20.7 & 18.2 & 1.1 & 16.2 & 81.7 \\
\hline & W1N2 & 15.6 & 1.8 & 22.7 & 20.7 & 1.6 & 26.8 & 20.3 & 1.3 & 21.4 & 18.8 & 1.1 & 16.8 & 87.7 \\
\hline & Average & 15.3 & 1.8 & 21.7 & 20.3 & 1.6 & 24.9 & 20.0 & 1.3 & 21.1 & 18.5 & 1.1 & 16.5 & 84.7 \\
\hline \multirow{3}{*}{$\begin{array}{l}\text { Shimai } \\
15\end{array}$} & W1N1 & 15.9 & 1.6 & 20.9 & 19.2 & 1.4 & 22.0 & 18.2 & 1.2 & 17.9 & 14.9 & 1.1 & 13.4 & 74.2 \\
\hline & W1N2 & 16.8 & 1.7 & 23.4 & 20.3 & 1.5 & 25.0 & 20.1 & 1.3 & 21.5 & 16.0 & 1.1 & 14.4 & 84.3 \\
\hline & Average & 16.4 & 1.7 & 22.2 & 19.8 & 1.5 & 23.5 & 19.2 & 1.3 & 19.7 & 15.5 & 1.1 & 13.9 & 79.3 \\
\hline
\end{tabular}

Table 7

Leaf area of individual plants at anthesis under limited irrigation and nitrogen supply (2010 2011)

\begin{tabular}{|c|c|c|c|c|c|c|}
\hline Variety & Regime & $\begin{array}{l}\text { Flag leaf } \\
\text { area }\left(\mathrm{cm}^{2}\right)\end{array}$ & The second leaf area $\left(\mathrm{cm}^{2}\right)$ & $\begin{array}{l}\text { The third leaf area } \\
\left(\mathrm{cm}^{2}\right)\end{array}$ & The fourth leaf area $\left(\mathrm{cm}^{2}\right)$ & $\begin{array}{l}\text { Total leaf area } \\
\left(\mathrm{cm}^{2}\right)\end{array}$ \\
\hline \multirow[t]{3}{*}{ Shimai 15} & W1Nb & $23.70 b$ & $29.08 b$ & $21.56 b$ & $13.08 a$ & $87.42 b$ \\
\hline & W1N1 & 29.18ab & $34.57 a b$ & $26.18 a$ & $14.38 \mathrm{a}$ & $104.31 a$ \\
\hline & W1N2 & $33.52 \mathrm{a}$ & $36.34 a$ & $26.45 a$ & $14.83 a$ & $111.14 a$ \\
\hline
\end{tabular}

\section{Changes in the leaf area index}

The leaf area index is an important indicator of the characteristics of light radiation in wheat populations. Table 8 and Table 9 show that as the leaf layer decreased from top to bottom, the leaf area index of the two wheat varieties decreased. Under the same limited irrigation conditions, the leaf area index in each layer in the N2 regime was higher than that in the N1 regime for both varieties. The leaf area index of Jimai 22 was higher than that of Shimai 15 in each layer. This vertical distribution pattern with a higher leaf area index in the middle and upper parts and a lower leaf area index at the bottom was not only conducive to the transmission of light from the upper to the lower layer but was also beneficial for the interception of light energy in the middle and lower layers. 
Table 8

Leaf area index of individual plants at anthesis under limited irrigation and nitrogen supply (2009 2010)

\begin{tabular}{|llllll|}
\hline Variety & Regime & Flag leaf & The second leaf & The third leaf & The fourth leaf \\
\hline Jimai 22 & W1N1 & 1.08 & 1.25 & 1.07 & 0.84 \\
\cline { 2 - 6 } & W1N2 & 1.19 & 1.34 & 1.12 & 0.87 \\
\cline { 2 - 6 } & Average & 1.13 & 1.29 & 1.09 & 0.85 \\
\hline \multirow{2}{*}{ Shimai 15 } & W1N1 & 1.03 & 1.11 & 0.91 & 0.67 \\
\cline { 2 - 6 } & W1N2 & 1.18 & 1.26 & 1.09 & 0.75 \\
\cline { 2 - 6 } & Average & 1.11 & 1.19 & 1.00 & 0.71 \\
\hline
\end{tabular}

Table 9

Leaf configuration of individual plants at anthesis under limited irrigation and nitrogen supply (2010 2011)

\section{Morphological characteristics of nodal layers}

Differences in plant height depend mainly on differences in node length, and the plant height composition index reflects the increasing trend of the length of each node from bottom to top. Table 10 and Table 11 show that as the node layer decreased from top to bottom, the length of each internode of both wheat varieties showed a decreasing trend, while the plant height composition index of two adjacent internodes showed an overall upward trend of increasing, followed by a decrease and then an increase. Under the same limited irrigation conditions, the length of the upper three nodes at the flowering stage accounted for approximately $70 \%$ of the plant height. The plant height and ear length of both varieties in the $\mathrm{N} 2$ regime were greater than those in the N1 treatment.

Table 10

Internode length and plant height component index at anthesis under limited irrigation and nitrogen supply (2009 2010)

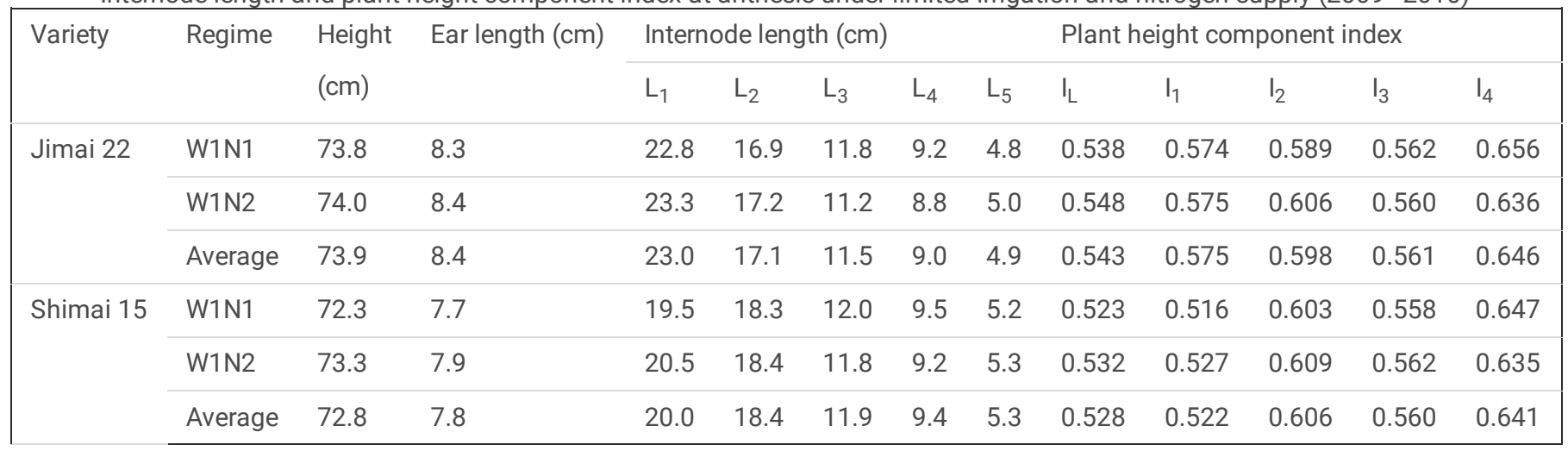

Table 11

Internode length and plant height component index at anthesis under limited irrigation and nitrogen supply (2010 2011)

\begin{tabular}{|c|c|c|c|c|c|c|c|c|c|c|c|c|c|}
\hline \multirow[t]{2}{*}{ Variety } & \multirow[t]{2}{*}{ Regime } & \multirow[t]{2}{*}{$\begin{array}{l}\text { Height } \\
(\mathrm{cm})\end{array}$} & \multirow[t]{2}{*}{$\begin{array}{l}\text { Ear } \\
\text { length }(\mathrm{cm})\end{array}$} & \multicolumn{5}{|c|}{$\begin{array}{l}\text { Internode length } \\
(\mathrm{cm})\end{array}$} & \multicolumn{5}{|c|}{ Plant height component index } \\
\hline & & & & $\mathrm{L}_{1}$ & $\mathrm{~L}_{2}$ & $\mathrm{~L}_{3}$ & $\mathrm{~L}_{4}$ & $\mathrm{~L}_{5}$ & $\mathrm{I}$ & $\mathrm{I}_{1}$ & $\mathrm{I}_{2}$ & $\mathrm{I}_{3}$ & $\mathrm{I}_{4}$ \\
\hline \multirow[t]{3}{*}{ Shimai 15} & $\mathrm{~W} 1 \mathrm{Nb}$ & 72.2 & 7.6 & 20.3 & 18.4 & 12.3 & 9.8 & 3.8 & 0.536 & 0.524 & 0.599 & 0.559 & 0.720 \\
\hline & W1N1 & 76.1 & 7.7 & 21.3 & 18.8 & 12.5 & 10.5 & 5.3 & 0.526 & 0.531 & 0.600 & 0.543 & 0.664 \\
\hline & W1N2 & 77.8 & 7.9 & 21.5 & 19.2 & 13.0 & 10.8 & 5.4 & 0.523 & 0.529 & 0.595 & 0.548 & 0.666 \\
\hline
\end{tabular}

The two wheat varieties had a similar plant height, but the length of the first five internodes of Jimai 22 was shorter than those of Shimai 15 , which indicated that Jimai 22 had stronger lodging resistance. The N1 regime shortened the length of the basal internodes and enhanced the 
lodging resistance of both wheat varieties. This not only conserves nitrogen but is also an effective lodging-resistant cultivation method. Suitable application of nitrogen at the jointing stage can effectively prevent wheat from lodging, which can increase yield.

\section{Variation characteristics of stem thickness}

At the late stage of wheat growth and development, due to the large amount of stalk storage material transported to the grain, the size of the medullary cavity between the stalk nodes changed.

Table 12 and Table 13 show that as the node layer decreased from top to bottom, the stem thickness of the two wheat varieties became the thickest in the first three nodes. Under the same limited irrigation conditions, the thickness of the internodes of the N2 regime was higher than that of the $\mathrm{N} 1$ regime in both varieties, except for five stems thick. Comparing the varieties, the stem thickness of each node layer of Jimai 22 was higher than that of Shimai 15, which indicated that Jimai 22 had a higher lodging resistance than Shimai 15.

Table 12

Stem diameter at anthesis under limited irrigation and nitrogen supply (2009 2010)

\begin{tabular}{|llllll|}
\hline Variety & Regime & $\begin{array}{l}\text { The first stem } \\
\text { diameter }(\mathbf{c m})\end{array}$ & $\begin{array}{l}\text { The second stem } \\
\text { diameter }(\mathbf{c m})\end{array}$ & $\begin{array}{l}\text { The third stem } \\
\text { diameter }(\mathbf{c m})\end{array}$ & $\begin{array}{l}\text { The fourth stem } \\
\text { diameter }(\mathbf{c m})\end{array}$ \\
\hline $\begin{array}{l}\text { Jimai } \\
22\end{array}$ & W1N1 & 0.478 & 0.490 & 0.499 & 0.489 \\
diameter $(\mathbf{c m})$
\end{tabular}

Table 13

Stem diameter at anthesis under limited irrigation and nitrogen supply (2010 2011)

\begin{tabular}{|llllll|}
\hline Variety & Regime & $\begin{array}{l}\text { The first stem } \\
\text { diameter }(\mathbf{c m})\end{array}$ & $\begin{array}{l}\text { The second stem } \\
\text { diameter }(\mathbf{c m})\end{array}$ & $\begin{array}{l}\text { The third stem } \\
\text { diameter }(\mathbf{c m})\end{array}$ & $\begin{array}{l}\text { The fourth stem } \\
\text { diameter }(\mathbf{c m})\end{array}$ \\
\hline $\begin{array}{l}\text { Shimai } \\
15\end{array}$ & W1Nb & $0.423 a$ & $0.451 \mathrm{a}$ & $0.454 \mathrm{a}$ & $\begin{array}{l}\text { The fifth stem } \\
\text { diameter }(\mathbf{c m})\end{array}$ \\
\hline W1N1 & $0.425 \mathrm{a}$ & $0.453 \mathrm{a}$ & $0.450 \mathrm{~b}$ & $0.431 \mathrm{~b}$ \\
\hline W1N2 & $0.427 \mathrm{a}$ & $0.461 \mathrm{a}$ & $0.463 \mathrm{a}$ & $0.457 \mathrm{ab}$ \\
\hline
\end{tabular}

\section{Dynamic characteristics of the temporal and spatial distribution of wheat canopy light transmittance}

Table 14 shows that with increasing canopy height, the light transmittance of the two wheat varieties showed an increasing trend, and the light transmittance of the middle part of the canopy was higher than that of the lower part. During the growth and development process, the light transmittance of the middle and lower parts increased and was highest at 20 days after flowering and lowest at the booting stage. Under the same limited irrigation conditions, the light transmittance of the N1 regime was higher than that of the N2 regime for both varieties. Under the same nitrogen level, the light transmittance of the W1 regime was higher than that of the W2 regime for both varieties. Under different water and nitrogen regimes, the light transmittance of Jimai 22 was generally higher than that of Shimai 15 . Figure 1 shows that with the decrease in the canopy level, the light transmittance decreased, reaching the maximum value at the flag leaf. Under the same limited irrigation conditions, the light transmittance decreased with increasing nitrogen application rate. Therefore, appropriate irrigation and nitrogen supply could improve the light distribution of the canopy and increase the light transmittance of the middle and lower layers at the jointing stage. 
Table 14

Canopy distribution of the light transmission rate under limited irrigation and nitrogen supply (2009 2010)

\begin{tabular}{|c|c|c|c|c|c|c|}
\hline Varieties & Light transmission rate (\%) & Regime & Booting & Anthesis & DAA10 & DAA20 \\
\hline \multirow[t]{10}{*}{ Jimai 22} & \multirow[t]{5}{*}{ Middle canopy } & W1N1 & $13.78 a$ & $15.24 a$ & $19.41 \mathrm{a}$ & $20.17 a$ \\
\hline & & W1N2 & $12.32 b$ & $11.94 b$ & $14.59 b$ & $16.24 b$ \\
\hline & & W2N1 & $13.78 a$ & $15.24 a$ & $18.43 a$ & $19.18 \mathrm{a}$ \\
\hline & & W2N2 & $12.32 b$ & $11.94 b$ & $12.70 b$ & $14.49 \mathrm{~b}$ \\
\hline & & Average & 13.05 & 13.59 & 16.28 & 17.52 \\
\hline & \multirow[t]{5}{*}{ Lower canopy } & W1N1 & $3.71 \mathrm{a}$ & $4.04 a$ & $4.66 a$ & $6.18 \mathrm{a}$ \\
\hline & & W1N2 & $2.94 b$ & $2.81 b$ & $3.91 b$ & $4.94 b$ \\
\hline & & W2N1 & $3.71 \mathrm{a}$ & $4.04 a$ & $4.29 a$ & $5.75 a$ \\
\hline & & W2N2 & $2.94 b$ & $2.81 b$ & $3.25 b$ & $4.25 b$ \\
\hline & & Average & 3.32 & 3.42 & 4.02 & 5.28 \\
\hline \multirow[t]{10}{*}{ Shimai 15} & \multirow[t]{5}{*}{ Middle canopy } & W1N1 & $12.72 a$ & $15.00 \mathrm{a}$ & $18.40 \mathrm{a}$ & $19.36 a$ \\
\hline & & W1N2 & $10.12 b$ & $10.05 b$ & $13.77 b$ & $14.80 \mathrm{c}$ \\
\hline & & W2N1 & $12.72 \mathrm{a}$ & $15.00 \mathrm{a}$ & $17.29 a$ & $17.67 \mathrm{~b}$ \\
\hline & & W2N2 & $10.78 b$ & $10.05 b$ & $12.60 \mathrm{~b}$ & $13.92 \mathrm{c}$ \\
\hline & & Average & 11.58 & 12.52 & 15.51 & 16.44 \\
\hline & \multirow[t]{5}{*}{ Lower canopy } & W1N1 & $2.83 a$ & $3.81 \mathrm{a}$ & $4.15 a$ & $5.76 a$ \\
\hline & & W1N2 & $2.54 b$ & $2.09 b$ & $3.00 \mathrm{~b}$ & $4.36 b$ \\
\hline & & W2N1 & $2.83 a$ & $3.81 a$ & $3.98 a$ & $5.66 a$ \\
\hline & & W2N2 & $2.54 b$ & $2.09 b$ & $2.99 b$ & $3.77 c$ \\
\hline & & Average & 2.68 & 2.95 & 3.53 & 4.89 \\
\hline
\end{tabular}

\section{Discussion And Conclusion}

\section{Morphological characteristics of leaves}

Leaf morphological characteristics are mainly based on the leaf length, leaf width and leaf area, which are among the important factors that affect the light distribution and interception in the canopy. A reasonable canopy structure is the basis for the formation of high crop yields, and nitrogen supply is an important factor that regulates the leaf area index (Zhang et al. 2011; Wang et al. 2011). Within a certain range, the leaf area index increases with increasing nitrogen application rate, which optimizes the light receiving posture for wheat plants (Huang et al. 2019). Studies have pointed out that under optimal fertilization treatment, the upper three leaves of wheat shorten, and the leaf area and leaf area index of the upper three leaves decrease, which increases the light transmittance and the light interception in the middle and lower layers of the wheat canopy (Li et al. 2007). Some scholars believe that the flag leaf should not be too long or too wide, the length of the first two leaves should be approximately $20 \mathrm{~cm}$, and the leaves should be tower-like, this kind of plant structure allows good light transmittance. The results of this study showed that as the leaf layer decreased from top to bottom, the leaf area and leaf area index of both varieties decreased. Under the same limited irrigation conditions, the leaf length, leaf width and leaf area of both varieties were higher in the N2 regime than in the N1 treatment. With the increase in the nitrogen application rate, the leaf area index increased, which is consistent with previous research results (Han et al. 2020) and Liu et al. (Liu et al. 2021). In each canopy layer, the leaf length, leaf width and leaf area of Jimai 22 were higher than those of Shimai 15. Therefore, the nitrogen fertilizer significantly increased the leaf length, leaf width and leaf area index of the upper three leaves of both varieties.

\section{Morphological characteristics of the stem}

Stem morphological characteristics are mainly based on the node length and stem thickness, and an appropriate node length and stem thickness play an important role in wheat yield (Ehdaie et al. 2006; Pheloung et al. 1991; Hu H et al. 2017). The characteristics of the basal internodes of wheat are closely related to lodging resistance. It is generally believed that short basal internodes, thick stem walls, and a high dry matter content per internode length are beneficial to lodging resistance (Xu et al. 2009; Wang et al, 2016; Yao et al. 2013). Within a certain range of plant heights, the ratio of the two basal nodes to plant height had a specific threshold that would not reduce the lodging resistance of the stem (Huang et al.

Page 9/12 
2021). With an increase in the nitrogen application rate and topdressing ratio, the basal internodes of wheat became increasingly thinner, and the stalk strength decreased (Zhang et al. 2014). This study showed that as the node layer decreased from top to bottom, the internode length of the two wheat varieties showed a decreasing trend, and the stem thickness reached the highest value at the third internode. Under the same limited irrigation conditions, the length of the upper three nodes at anthesis accounted for approximately $70 \%$ of the plant height, except for the five internode length and the five stem diameter, the length of each internode and the stem thickness of both varieties in the N2 regimewere higher than those in the N1 treatment. With an increase in the nitrogen application rate, the plant height, internode length and stem thickness increased. Comparing between varieties, the plant heights and the stem thickness of each node layer of Jimai 22 was higher than that of Shimai 15. Therefore, proper irrigation and nitrogen supply has a certain lodging resistance, which is conducive to obtaining high yields.

\section{Characteristics of light transmittance}

Light transmittance is an important parameter that reflects the relationship between light distribution and canopy structure in a plant population. The leaves play the most important role in the canopy structure, while the light distribution is strongly affected by the leaf position. Studies have shown that with an increase in wheat planting density, the light transmittance in the middle and low canopy levels is relatively low (Ding et al. 2020). With an increase in nitrogen fertilizer, the light transmittance in the middle and lower parts of a winter wheat canopy showed a trend of first decreasing and then increasing (Lei et al. 2017). The results of this study showed that under the same limited irrigation conditions, the light transmittance in the N1 regime was higher than that in the N2 regime for both varieties. Under the same nitrogen level, the light transmittance in the $\mathrm{W} 1$ regime was higher than that in the $\mathrm{W} 2$ regime for both varieties, and under different irrigation and nitrogen regimes, the light transmittance of Jimai 22 was generally higher than that of Shimai 15. With increasing canopy height, the light transmittance of the population showed an increasing trend, and the light transmittance of the middle part was higher than that of the lower part. During the growth and development process, the light transmittance of both varieties showed an overall increasing trend. With an increase in the nitrogen application rate, the light transmittance in each leaf layer showed a downward trend.

Based on the above conclusions, nitrogen application can alter the characteristics of the leaf layer and node layer in wheat, shorten the length of the basal internode, and increase the light transmittance in the middle and lower parts of the population. Under the condition of limited irrigation, when the nitrogen application rate was $192 \mathrm{~kg} / \mathrm{hm}^{2}$, the yield of the two wheat varieties reached $9954.61 \mathrm{~kg} / \mathrm{hm}{ }^{2}$, and the nitrogen fertilizer production efficiency was $23.49 \mathrm{~kg} / \mathrm{kg}$, which can be used as a reference for actual production.

\section{Declarations}

\section{Acknowledgments}

This study was funded by the Key Science and Technology Projects in Henan Province (Contract Number: 212102110253) and the National Key R\&D Program (Contract Number: 2016YFD0300401).

\section{References}

1. Ding WH, Jiang X, I, Feng S, w, Jin L, Lu Y, Ru Z (2020) Effects of sowing rate on photosynthetic characteristics, material accumulation and yield of BNS hybrid wheat. North China Agricultural Journal. 35(4):113-119. doi:10.7668 /hbnxb.20191054

2. Dordas CA, Sioulas C (2009) Dry matter and nitrogen accumulation, partitioning, and retranslocation in safflower (Carthamus tinctorius L.) as affected by nitrogen fertilization. Field Crops Research 110:35-43. doi: 10.1016/j.fcr.2008.06.011

3. drinkwater LE, Snapp SS (2007) Nutrients in agroecosystems: rethinking and the management Paradigm. Advances in Agronomy 92:163186. doi: 10.1016/S0065-2113(04)92003-2

4. Ehdaie B, Allous h GA, Madore MA, waines j g (2006) Genotypic variation for stem reserves and mobilization in wheat. Crop Sci 46:735-746. doi: 10.2135/cropsci2005.04-0033

5. Han L, Dong W, Zhang Y (2020) Effects of different water and fertilizer treatments on wheat canopy structure, yield and grain quality. Journal of Zhejiang Agriculture. 32(6): 953-962. doi: 10. 3969 /j.issn.1004-1524. 2020. 06. 02

6. Huang B, Zhang Y, Sun J q, chen x, zhang I, zhu y l, liu h h, wei f z, song y h, li j c. 2019. Effects of nitrogen density interaction on photosynthetic characteristics and yield of wheat canopy in Huaibei Shajiang black soil area.Journal of Triticeae Crops.39(8):994-1002. doi: 10.7606/j.issn.1009-1041.2019.08.15

7. Hu H, Li SS, Hua H, Sun MM, Kang J, Xia G, Wang CY (2017) Research on stalk morphological structure characteristics and its relationship between with the lodging of different wheat varieties. Journal of Triticeae Crops 37(10):1343-1348. doi: 10.7606/j.issn.10091041.2017.10.10

8. Huang L, Yang W, p, Mei P, Jiao S, Xu L, n, Zhang Z, Ou X, Yao S (2021) m. Study on lodging resistance characteristics of different wheat varieties (lines) in sandy de-humid soil area. Journal of Irrigation and Drainage. 40(3):31-39. doi: 10.13522/j.cnki.ggps.2020420 
9. Jiang L, Ma J, Fang B, t, Ma J, Li C, Wang Z, Hao B (2019) Effects of limiting water and reducing nitrogen on wheat yield and dry matter transfer in different levels of plant organs in northern Henan. Acta Agronomica Sinica. 45(6):957-966. doi: 10.3724/SP.J.1006.2019.81068

10. Jing Q, Bouman BAM, Hengsdijk H, Keulen HV, Cao W (2007) Exploring options to combine high yields with high nitrogen use efficiencies in irrigated rice in China. Eur J Agron 26(2):166-177. doi:10.1016/j.eja.2006.09.005

11. Laghari GM, Oad FC, Tunio S, Gandahi AW, Oad SM (2010) Growth, yield and nutrient uptake of various wheat cultivars under different fertilizer regimes. Sarhad Journal of Agriculture 26(4):489-497

12. Lei J, Zhang Y, w Chen X, Sailihan S, Xue L, Fan G, Wang Z (2017) m. Effects of nitrogen application rate on the canopy structure andicroclimate characteristics of winter wheat under drip irrigation in Xinjiang. Journal of China Agricultural University. 22(10):1-14. doi: 10. $1184 / J$. ISSN. 1007-4333.2017.10.01

13. li D, d M, cai J, Jiang D, cao W, dai T (2013) Effects of low nitrogen supply on relationships between photosynthesis and nitrogen status at different leaf position in wheat seedlings. Plant Growth Regulation. 70(3):257-263. doi: 10.1007/s10725-013-9797-4

14. Li G, Tang L, Zhang W y, cao w x, zhu y. 2011. Effects of nitrogen application rate on the vertical distribution characteristics of leaf types of different plant types of wheat varieties.Acta Agronomica Sinica.37(1):127-137. doi: 10.3724/SP.J.1006.2011.00127

15. Li PF, Cheng Z, Zhao H zhang x f, li j n, wang s m, xiong y c. 2011. Research progress on ideal plant type of dryland wheat. Acta Ecologica Sinica. 31(9): 2631-2640

16. Li Z, Guo Y, Wang P zhai z x, zilkens $\mathrm{m}$ b. 2007. Differences in wheat canopy structure under several water and nitrogen treatments. Acta Triticeae Sinica. 27(6): 1088

17. Liu Y, Yang M, Yao CS, Zhou XN, Zhang YH (2021) Optimum Water and Nitrogen Management Increases Grain Yield and Resource Use Efficiency by Optimizing Canopy Structure in Wheat. Agronomy 11(3):441. doi: 10.3390/agronomy11030441

18. Ma J, Fang B, t, Qiao Y, Li CX, Wang ZM, Hao BZ, Jiang LN (2019) Effects of nitrogen reduction on canopy structure and photosynthetic characteristics of water-limited irrigation wheat in northern Henan. Triticeae Crops 39(3):346-355

19. Pheloung PC, Siddique KHM (1991) Contribution of stem dry matter to grain yield in wheat cultivars. Australian Journal of Plant Physiology 18(1):53-64. doi: 10.1071/PP9910053

20. Vos J, Vander Putten PEL, Birch CJ (2005) Effect of nitrogen supply on leaf appearance, leaf growth, leaf nitrogen economy and photosynthetic capacity in maize (Zea mays L.). Field Crops Research 93(1):64-73. doi: 10.1016/j.fcr.2004.09.013

21. Wang C (2011) The effect of nitrogen fertilizer level and planting density on the structure and function of wheat canopy. Tai'an: Shandong Agricultural University. doi: 10.7666/d.d143542

22. Wang D, Ding WH, Feng SW, Hu TZ, Li G, Li XH, Yang YY, Ru ZG (2016) Stem characteristics of different wheat varieties and its relationship with lodging-resistance. Chin J Appl Ecol 27(5):1496-1502. 10.13287 /j.1001-9332.201605.039

23. Wang Z, Wang P, Li X, h LI j m, lu I q. 2006. Simplified cultivation theory and technology of water-efficient, fertilizer-efficient and high-yielding wheat.Review of China Agricultural Science and Technology. 8(5):38-44

24. Xu L, Wang DW, Shi RS, Sheng ZF, Li AF (2009) Relationship between Lodging-resistance and the Density of the Bottom Elongate Stem in Wheat. Journal of Triticeae Crops 29(4):673-679

25. Yang M, Huang Q, Zhang Z, Liu Y, Wang ZM, Zhang YH (2021) Effects of C and N supply on grain number, grain weight and protein content of wheat ears under in vitro ear culture conditions. Journal of Triticeae Crops 41(3):328-337. 10.7606/j.issn. 1009-1041.2021.03.09

26. Yao JB, Ma HX, Yao GC, Yang XM, Zhou MP, Zhang PP, Zhang P (2013) Research Progress on Lodging Resistance in Wheat (Triticum aestivum L.). Journal of Plant Genetic Resources 14(2):208-213. doi:10.13430/j.cnki.jpgr.2013.02.016

27. Zhang FS, Cui ZL, Wang JQ, Li Chun J, Chen XP (2007) Status and improvement strategies of soil and plant nutrient management in China. Botany Bulletin 24(6):687-694. doi: 10.3969/j.issn.1674-3466.2007.06.001

28. Zang HC, Liu YP, Cao L, Zhang YH, Wang ZM (2012) Nitrogen absorption and utilization characteristics of two high-yielding wheat varieties under limited water and nitrogen supply. Triticeae Crops 32(3):503-509

29. Zhang M, Yi Y, Dong Z, d, Ke P, Zhu X, Feng CN, Guo WS, Peng YX (2014) Effects of nitrogen fertilizer on stalk traits and lodging resistance of Yangmai 20. Journal of Triticeae Crops. 34(9):1260-1266. doi: 10.7606/j.issn.1009-1041.2014.09.15

30. Zhang WJ, Jiang DG, Huang ZL, Zhou XN, Ma SY, Mi L, Han X, Wang C (2018) y. Effects of nitrogen fertilizer on canopy structure,ield and quality of rice stubble wheat. Journal of Triticeae Crops, 2018, 38(2):164-174. doi: 10.7606/j. issn. 1009-1041. 2018.02.07

31. Zhang Y, Wang Z (2011) Characteristics of canopy structure and contributions of non-leaf organs to yield in winter wheat under different irrigated conditions. Field Crops Research 123(3):187. doi: 10.1016/j.fcr.2011.04.014

32. Zhao ZG, Qin X, Zang HC, Chen C, Zhang YH, Wang ZM (2017) Value of groundwater used for producing extra grain in North China Plain. Field Crops Research 210:47-51. doi: 10.1016/j.fcr.2017.05.022

33. Zhou J, Wang X, Zhu Y, I, Liu H, Chen X, Wei F, z, Sun J, Song Y, Li J (2019) Effects of nitrogen fertilizer management model on lodging resistance and yield of wheat stems. Journal of Triticeae Crops. 39(8): 979-987. doi: 10. 7606/j. issn. 1009-1041. 2019. 08.13 
Figures

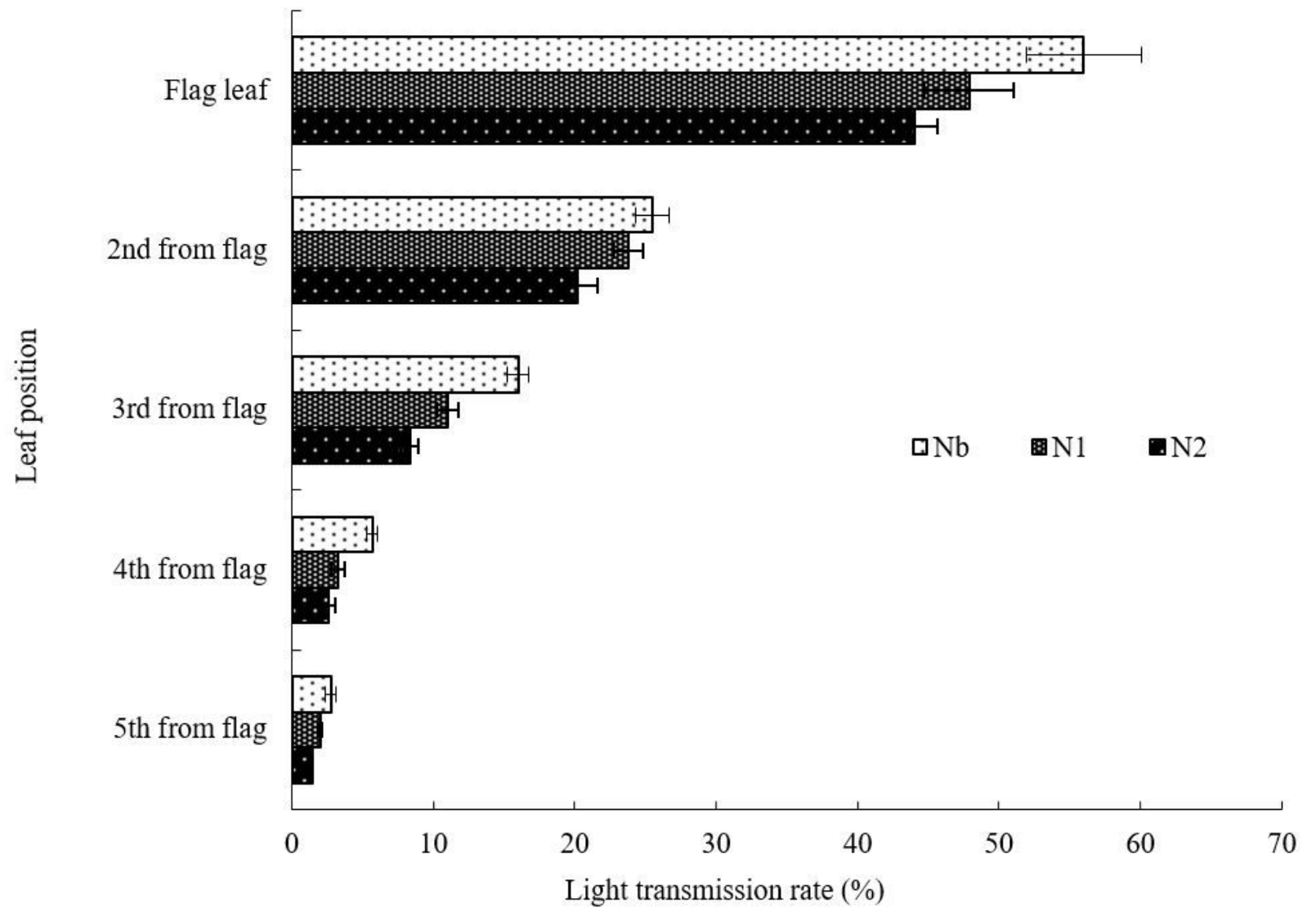

Figure 1

Canopy distribution of the light transmission rate at anthesis under limited irrigation and nitrogen supply (2010 2011) 